\title{
Intangibles: A Puffing of the Wares?
}

\author{
John H. Nugent (Corresponding author) \\ DBA, LLM, CPA, CFE, CISM, FCPA, Associate Professor \\ Texas Woman's University College of Business, Denton, TX, US \\ Tel: 214-682-8025Ｅ-mail: jnugent @twu.edu \\ Alex Pomelnikov \\ Ph.D., Lecturer, Texas Woman's University College of Business \\ Denton, TX, US
}

Tel: 940-898-2114

Kerry Webb

Ph.D., Associate Professor, Texas Woman's University College of Business

Denton, TX, US

Tel: 940-898-2104

Received: January 30, 2019 Accepted: February 21, 2019 Published: February 26, 2019

doi:10.5296/ijafr.v9i1.14301

URL: https://doi.org/10.5296/ijafr.v9i1.14301

"Perception is often the ultimate mask for reality." Attributed to the Hilliard Consulting Group, 2001.

\begin{abstract}
This paper examines the issue of perceived value generated by the assignment of financial value to intangibles in financial reporting. In particular, values assigned to Goodwill and other intangibles in mergers and acquisitions are examined, and the impact of such intangible valuations as a potential misperception/misdirection as to true underlying entity value is examined. Finally, the question of enterprise maturity and sustainability posed by Greiner (1972) in the current U.S. Regulatory environment is answered with clarity.
\end{abstract}

Keywords: APB, ASC, AICPA, FASB, FMV, Goodwill, Growth, Impairment, Intangibles, M\&A, Profits, Profit maximization, SEC, Sustainability, Tangibles

\section{Introduction}

Under the U.S. Financial Accounting Standards Board's (FASB's) standards today, its Accounting Standards Codification (ASC) rules provide significant leeway as to the values assigned to net assets acquired, particularly evident in mergers and acquisitions concerning the values assigned to 


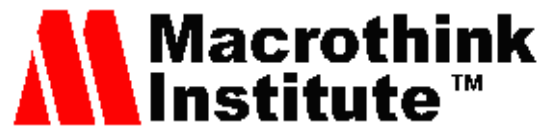

International Journal of Accounting and Financial Reporting

ISSN 2162-3082

2019, Vol. 9, No. 1

intangibles. In particular, values assigned to Goodwill. Goodwill Additionally, under the current standards, the wasting of those intangible asset values as they become impaired (expensed), provide wide discretion as to how such assets are valued and when they are impaired (expensed).

Previously, one of the largest categories of intangibles, 'Goodwill', was to be amortized (expensed) over a period of time for which the asset provided benefits to the enterprise, but not to exceed 40 years. This method of dealing with Goodwill was established by American Institute of Certified Public Accountants' (AICPA's) Accounting Principles Board in (APB) 17, Intangible Assets, August 1970. This rule established a systematic and rational basis for dealing with the expensing of intangibles including Goodwill, which narrowed the amount of discretion executives had; specifically, the method and the number of years over which intangibles would be expensed. The APB 17 standard provided the basis for an annual charge against intangible assets that appeared in the Income Statement as an expense, similar to the depreciation of a physical asset, which represented the diminishment of asset value in a systematic and rational process as it was consumed in the production of revenue. Thus, annual expensing of these intangible assets introduced constraints on discretion in applying the prudence and conservatism principles of accounting conceptual fundamentals at the time.

However today, the body that became the Accounting Standards Board's successor, The Financial Accounting Standards Board (FASB), has elected to follow a looser 'unless and until' impairment standard regarding intangibles. Superseding APB 17, Statement of Financial Accounting Standard (SFAS) 142, 'Goodwill and Other Intangible Assets,' June 2001, required the use of the impairment charge method of expensing intangibles including Goodwill. That is, Goodwill was not to be systematically and rationally amortized anymore; rather, it was to henceforth be 'impaired', if and when impairment occurred. That is, intangibles were not to be expensed unless and until impairment occurred - a value as principally determined in the eye of the beholder approach. U.S. Generally Accepted Accounting Principles (GAAP) are based on its standards being systematic and rational, and not subject materially to the whim and discretion of executives' perceptions, which may sometimes be deemed arbitrary and capricious. The 'impairment rule' in use today is still the rule under the FASB's SFAS 142 as codified in its Accounting Standards Codification (ASC) as FASB Accounting Standards Update (ASU) 2012-02, issued July 2012, Topic 350, and now appearing in a draft update.

Other intangibles of note that are subject to the same treatment today as Goodwill are represented by intangible assets such as: customer lists, brand names, intellectual property, etc. As each intangible asset is unique, the fundamental problem lies in valuing (few to no benchmarks are available) and estimating a useful life. This issue ultimately becomes a discretionary judgment call by enterprise executives. The previous APB 17 rule mitigated to a large degree the discretion in the expensing of such assets.

\section{Intangibles}

General intangibles are defined in the Uniform Commercial Code (U.C.C) in Article 9-Definitions, as: any personal property that is not an account, chattel paper, commercial tort claim, deposit account, document, instrument, goods, investment property, letter-of-credit right, letter of credit, money, or mineral before extraction especially as identified by section 9-102 of the Uniform Commercial Code (n. d.).

More specifically and simply, intangibles are assets which have the following characteristics: "incapable of being perceived by touch; impalpable, are imprecise or unclear to the mind, or are saleable, though not possessing intrinsic productive value" (The Free Dictionary, n. d.)

FASB under its accounting authority, specifically in its Accounting Standards Codification (ASC) governing the accounting for intangibles and Goodwill, sections 350-10, 350-20 and subtopic 850-30, addresses the issues of, and issues associated with, intangibles including Goodwill. In particular, paragraph ASC 350-10-05-1 provides guidance on financial accounting and reporting related to Goodwill. Paragraph ASC 850-30-30-1) Measurement of Goodwill, posits: the acquirer shall 


\section{MInstitute Macrothink $_{\text {Int }}$}

International Journal of Accounting and Financial Reporting

ISSN 2162-3082

2019, Vol. 9, No. 1

recognize Goodwill as of the acquisition date, measured as the excess of (a) over (b) where (a) is the aggregate of the consideration transferred; the fair value of any non controlling interest in the acquired; the business combination achieved in stages and (b) is the net of the acquisition-date amounts of the identifiable assets acquired and the liabilities assumed measured in accordance with this Topic.

The Accounting Standard Codification (ASC 350-10-20) also describes Goodwill, “...as an asset representing the future economic benefits arising from other assets acquired in a business combination or an acquisition by a not-for-profit entity that are not individually identified and separately recognized."

In simple terms, Goodwill is generally a long term asset of an intangible nature that arises when a company acquires another business in its entirety. Goodwill is calculated as follows:

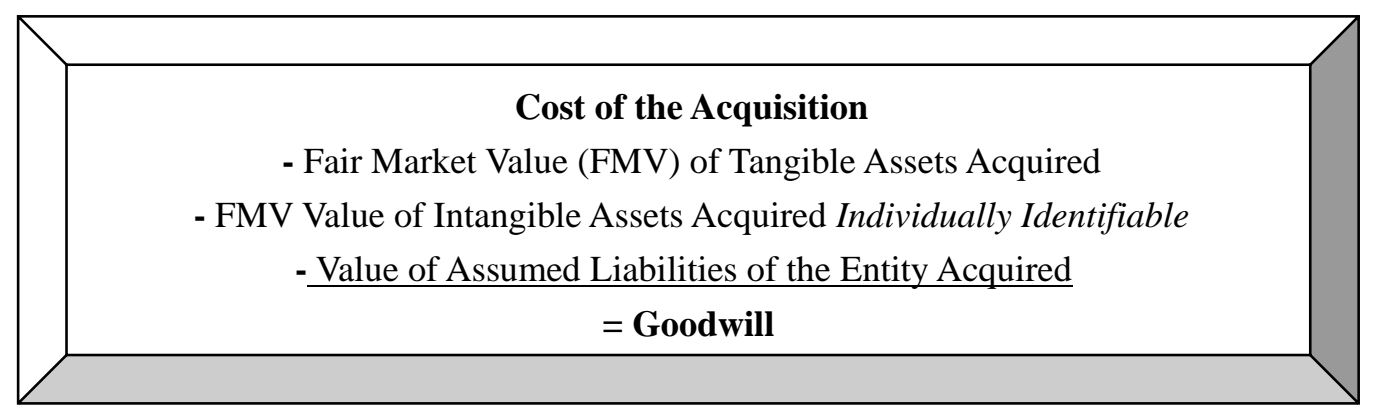

Figure 1. Intangibles - the Goodwill calculation

Even more simply, Goodwill is the net asset value of net assets acquired in excess of their Fair Market Value that cannot be individually identified.

\section{Facts and Historical Points - The Rules}

Many of the issues in dealing with intangibles including Goodwill arose when the former Accounting Principles Board (predecessor to the Financial Accounting Standards Board - FASB) in its Opinion, APB No. 16, 'Business Combinations', permitted two methods of accounting for acquisitions: 1) the purchase acquisition rule where Goodwill had to be calculated, and 2) the pooling acquisition rule which permitted firms to simply merge like kind account balances (no write-up of asset values to fair market value). APB 16 required the pooling method to be used, but then laid out a series of rules which were difficult for firms to meet in adopting the pooling method. Unless all the pooling combination rules could be met, the purchase method had to be used. The effect was many firms had to use the purchase method for business combinations. APB No. 16 was superseded with the FASB issuance of its Statement No. 141 (SFAS 141), 'Business Combinations', which only permitted the purchase method to be used for accounting for business acquisitions. To date, the purchase method of accounting for business combinations stands.

Additionally, FASB Concepts Statement 2 (CON 2), (May 1990), Qualitative Characteristics of Accounting Information, in paragraphs 91-93, addresses the matter of making the conservative choice when deciding accounting matters.

91. Nothing has yet been said about conservatism, a convention that many accountants believe to be appropriate in making accounting decisions. To quote APB Statement 4: Frequently, assets and liabilities are measured in a context of significant uncertainties. Historically, managers, investors, and accountants have generally preferred that possible errors in measurement be in the direction of understatement rather than overstatement of net income and net assets.

This has led to the convention of conservatism [paragraph 171]. 


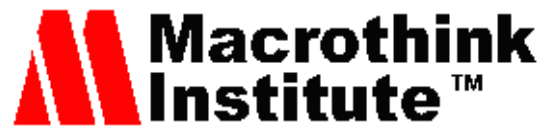

International Journal of Accounting and Financial Reporting

ISSN 2162-3082

2019, Vol. 9, No. 1

92. There is a place for a convention such as conservatism-meaning prudence-in financial accounting and reporting, because business and economic activities are surrounded by uncertainty, but it needs to be applied with care. Since a preference "that possible errors in measurement be in the direction of understatement rather than overstatement of net income and net assets" introduces a bias into financial reporting, conservatism tends to conflict with significant qualitative characteristics, such as representational faithfulness, neutrality, and comparability (including consistency). To be clear about what conservatism does not mean may often be as important as to be clear about what it means.

93. Conservatism in financial reporting should no longer connote deliberate, consistent understatement of net assets and profits. The Board emphasizes that point because conservatism has long been identified with the idea that deliberate understatement is a virtue. That notion became deeply ingrained and is still in evidence despite efforts over the past 40 years to change it. The convention of conservatism, which was once commonly expressed in the admonition to "anticipate no profits but anticipate all losses," developed during a time when balance sheets were considered the primary (and often only) financial statement, and details of profits or other operating results were rarely provided outside business enterprises. To the bankers or other lenders who were the principal external users of financial statements, understatement for its own sake became widely considered to be desirable, since the greater the understatement of assets the greater the margin of safety the assets provided as security for loans or other debts.

However, the FASB with its issuance of SFAC 8, September 8, 2010, 'Qualitative Characteristics of Accounting Information' which superseded CON 2, changed its long standing practice of a preference for the conservative choice. In Para BC3.27 of SFAS 8 (also referred to as CON 8), the FASB no longer included 'prudence or conservatism' as an aspect of neutrality. Hence, the new ...unless and until... impairment treatment for Intangibles and Goodwill became the standard in place till today.

\section{Discussion of the Issues}

In the recent past, it was noted in Forbes Magazine (Oct. 16, 2006), when reviewing the new, at the time, FASB's Fair Value Reporting Standard, SFAS 157, Fair Value Measurements, September 2006 (now re-classed as FASB ASC 820, Fair Value Measurements and Disclosures), that large issues loomed regarding intangibles and their valuations. Here, Forbes reported that Verizon Corporation carried on its books approximately $\$ 48$ billion in wireless license fees paid to the FCC for spectrum. The issue arose when the FCC subsequently auctioned off twice as much spectrum as Verizon held for approximately $\$ 14$ billion. By dividing the $\$ 14$ billion by 2, we can see the FCC auctioned off approximately the same amount of spectrum as Verizon held for $\$ 7$ billion - a $\$ 41$ billion delta from what appeared on Verizon's books paid for licenses. Here Verizon would likely have had to show this was not a market comparable (marked to market) - our spectrum is different than the recently auctioned off FCC spectrum, and use the fall back value method of justifying its spectrum value with a net present value discounted cash flow estimation based on the spectrum held. But $\$ 41$ billion is $\$ 41$ billion on anyone's books, and represents a huge delta from a marked to market basis!

In more recent times, we see a tremendous growth in the appearance of intangibles on the balance sheets of many companies in order to show top line and bottom line growth in an otherwise satiated market. That is, when few green fields remain (few unclaimed customers in a given industry), entities start buying others to feed Wall Street's need to see top and bottom line growth period over period in order to sustain market values. Such acquisitions in periods where margin and growth without acquisitions are being squeezed, tend to drive managements to find a way to show material top and bottom line growth other than via organic growth. Unfortunately, in such acquisitions, material layoffs often follow in order to capture accretive financial benefits. 


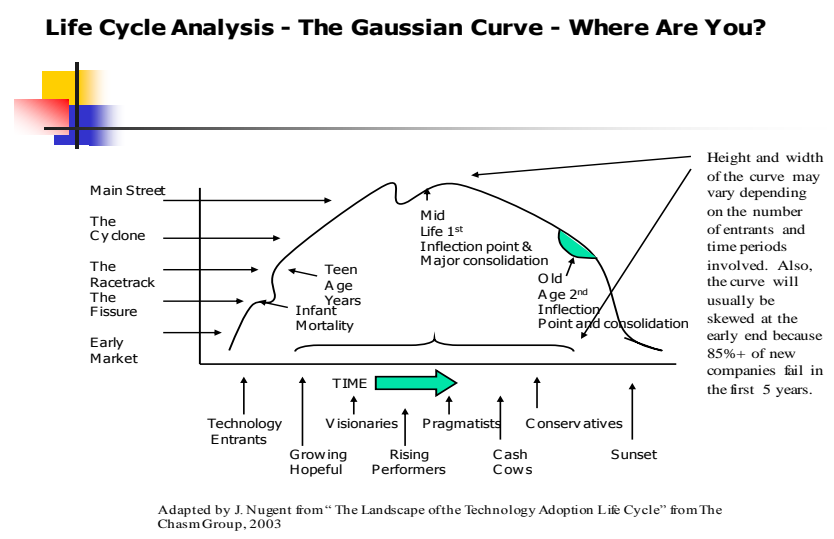

Figure 2. Life cycle analysis - the Gaussian curve - where are you?

It is important to understand that all things in life have their respective life cycles. And such life cycles affect behavior and sustainability. Examples here are that the most newly formed entities fail in the first five years of life (Infant Mortality Syndrome) where 80 to $85+\%$ fail, with the average business entity life expectancy of all firms being 12.5 years (Senge, 2013, and Nugent, 2003). We see such life cycles apply to nations and states as well. Here Tytler (1787) posited no democracy had ever survived for more than 300 years, and most not more than 200 years. And Cicero (55 B.C.) and Ibn Khaldoun (1377) posited similar understandings - that is, all systems have a life cycle. And behavior determines the length of a life cycle. For additional discussion of a corporate entity's passage through its life cycle, see also John Argenti's work, "Corporate Collapse - The Causes and Symptoms," (1976).

As a recent example of how acquiring an entity outside of its core business activity can dramatically shorten and entity's life cycle, we need to look no further that the old AT\&T (1984 to the mid 2000s). It was in this period AT\&T made the decision to have to acquire cable companies to compete with the Regional Bell Operating Companies (RBOCs). Here AT\&T paid large premiums to acquire such cable companies. By applying a "Bottoms - Up" analysis, one could determine why such acquisitions would significantly shorten AT\&T's life.

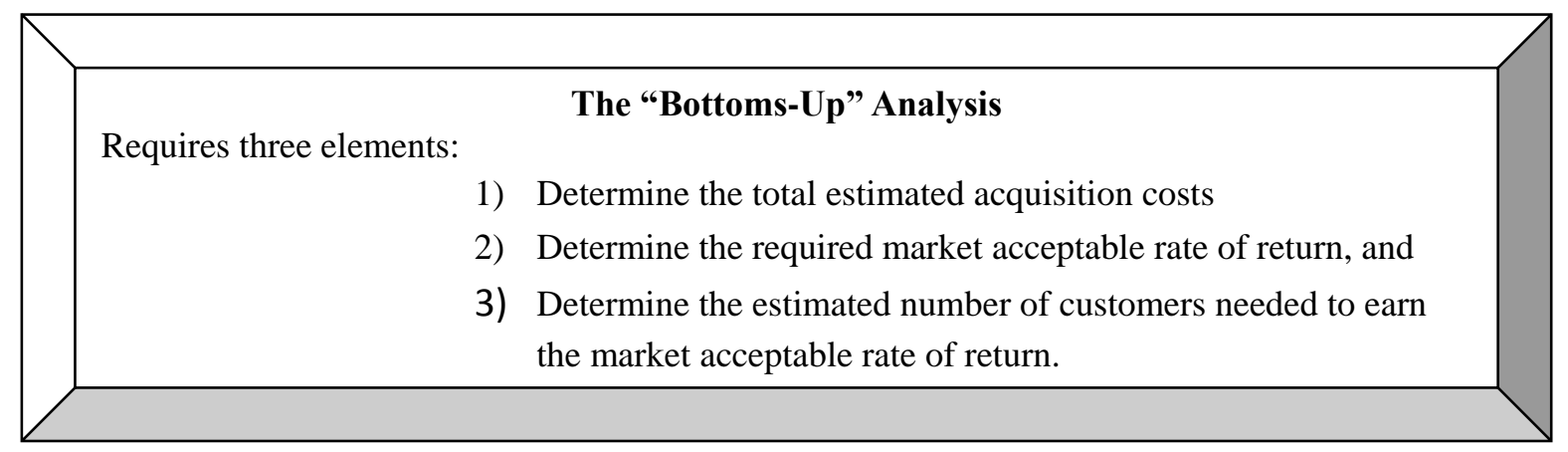

Figure 3. The "Bottoms-Up" analysis

The public early estimate for AT\&T's cable acquisitions was put at approximately $\$ 120$ billion. But the cable systems needed to be upgraded so they were two-way broadband systems, versus 450 megahertz one-way systems. The broadband upgrade cost was estimated to be $\$ 20$ billion. Moreover, as AT\&T wished to transmit voice over such cable systems, it now had to provide a battery solution for its acquired cable grid, as the FCC requires the provision of voice service without power from the electric grid for eight hours. The power solution was estimated to be $\$ 10$ billion for a total estimated investment of $\$ 150$ billion. The acceptable market rate of return at the time was approximately $10 \%$. This means from day one after the investments, AT\&T would have to have earned $\$ 15$ billion net a year to earn the market acceptable rate of return. Estimating every AT\&T potential customer would 


\section{MInstitute ${ }_{\text {Mnk }}^{\text {Macrothink }}$}

pay $\$ 100$ every month (a very high amount for all customers), and that AT\&T would earn a $12.5 \%$ rate of return $(\$ 100 \times 12$ months $=\$ 1,200 \times 12.5 \%=\$ 150$ net per customer per year), AT\&T would net $\$ 150$ per year per customer. Dividing the required return of $\$ 15$ billion a year by the average estimated net per customer (\$150), it could be seen AT\&T would have to capture almost immediately $100,000,000$ customers to make an acceptable rate of return. But at the time of the cable acquisitions, there were only $108,000,000$ households in the U.S. with $15 \%$ of those households below the poverty line. Not to mention all the customers already captured by competitors. In essence, there was no way for AT\&T to achieve its market acceptable rate of return. But with the ability to book gross over payments above net asset fair market values, and allowing such values to be placed on the balance sheet as an asset (Goodwill), and not having to expense (impair) such Goodwill unless and until impairment occurred, provided for a time a misallocation of resources with no adequate concomitant return. Such a decision imperiled long term sustainability.

Material acquisitions in an industry as shown in the Life Cycle diagram above typically take place in two phases. The first consolidation point occurs at approximately $50 \%$ market satiation. Here market concentrations remain under statuary concentration limit thresholds (Herfindahl - Hirschman, 2010). However, it is where later in life at the second consolidation point that market leaders driven by growth imperatives in an industry buy one another in an attempt to show material growth. Just beyond this second consolidation point, the current U.S. regulatory environment will not permit horizontal acquisitions. This was the recent case of AT\&T's attempt to acquire T Mobile in a horizontal acquisition several years ago.

The driver in horizontal and vertical acquisitions then often result in material Goodwill and other intangibles (values placed on customer lists for example) appearing on the balance sheet. This was the case in AT\&T's acquisition of DirecTV for $\$ 48$ billion, with the assumption of another $\$ 20$ billion in debt (total acquisition cost $\$ 68$ billion). However, this latter acquisition was in an industry where AT\&T lacked deep knowledge and experience. The result is that AT\&T has suffered material churn (loss of customers) in its DirecTV subsidiary thereby shortening its potential life cycle. Compounding this fact, AT\&T then introduced DirecTV Now. The problem is AT\&T undercut its $\$ 68$ billion acquisition for DirecTV with its new DirecTV Now offering. DirecTV customers averaged $\$ 117$ a month, where DirecTV Now customers were paying $\$ 50$ a month. So with large churn in DirecTV customers, earning a market acceptable rate of return on the DirecTV acquisition with a cost of $\$ 68$ billion appears very unlikely. But how materially will AT\&T impair its Goodwill?

It was reported in The Wall Street Journal that companies in the U.S. could have recorded more than $\$ 8$ trillion in intangible assets (including Goodwill) according to Leonard Nakamura of the Federal Reserve Bank of Philadelphia (2016). Monga states, “... that's nearly half of the combined $\$ 17.9$ trillion market capitalization of the S\&P 500 index (Monga 2016). Bernard Condon of Associated Press (2016) indicates that Goodwill on the balance sheets of the Standard \& Poor's 500 index ballooned to $\$ 2.5$ trillion. "That is $50 \%$ more than at the end of the last deal boom in 2007 according to FactSet" (Condon, 2016).

And as Thurm (2012) shows below, we see many examples of where Goodwill on the balance sheet approaches or far exceeds an entity's total market value (shares outstanding times the per share market price of the shares outstanding). 


\section{Mll Macrothink}

International Journal of Accounting and Financial Reporting

ISSN 2162-3082

2019, Vol. 9, No. 1

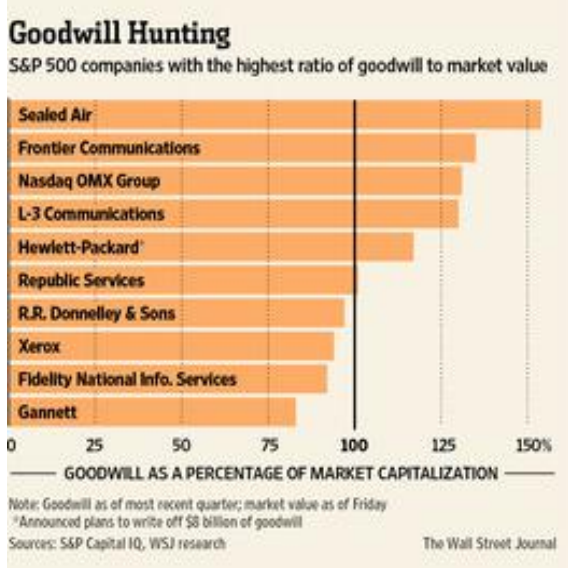

Figure 4. Goodwill Hunting Source: Thurm (2012)

The effect of the move to booking large Goodwill amounts according to data provided by R.G. Associates, a research firm that focuses on accounting matters, shows that in 2002 following a surge in acquisitions, accounting write-downs cut pre-tax earnings by $21 \%$, while Goodwill write downs in the twelve months following the end of 2007 reduced S\&P 500 earnings by more than $38 \%$ (Condon, 2016).

The challenge in post second phase acquisitions (see the Life Cycle Model above), is that they mostly are vertical acquisitions up and down the supply chain, or outside the acquirer's core industry because of regulatory market concentration limits. Such acquisitions in different industry sectors pose significant challenges and risks often in areas where the acquirer has limited industry knowledge and experience.

Condon further identifies the issues with Goodwill values. He posits that the average premium over market prices offered by acquirers in 2015 was $38 \%$, and for health care companies, the premium offered was 57\% (Condon, 2016). To some, such premiums over market value appear as gross overpayments above what the market reflected as value.

The figure below, Figure 5 presents reported Intangibles including Goodwill of 19 of the largest U.S. publicly listed companies with the largest Goodwill. This table also presents a view of intangibles and Goodwill relative to each entities total assets and market capitalization measures.

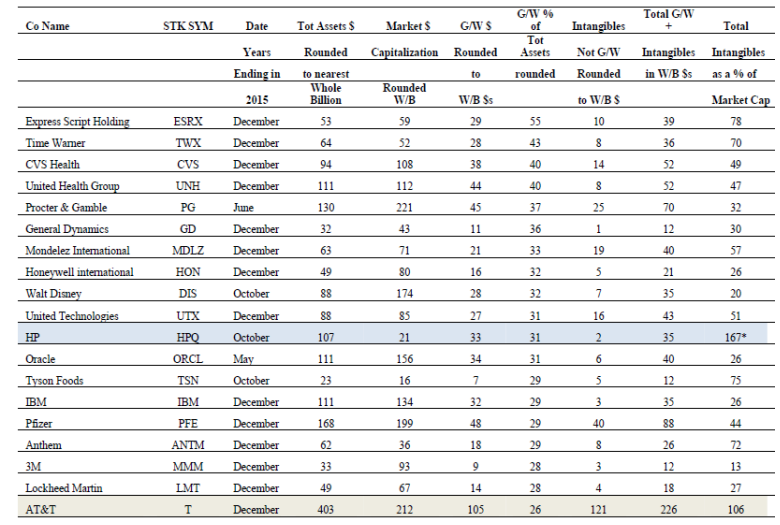

Figure 5. Total assets, market caps, Goodwill and intangibles (in Billions of \$'s rounded to nearest

Whole Billion for, Years ending in 2015 -months vary)

Sources: Forbes Magazine, June 15, 2016, www.sec.gov/edgar, \& Siblis Research

*Note: HP's numbers above are distorted due to the breakup of HP into two separate enterprises in this period. 


\section{MlMacrothink}

International Journal of Accounting and Financial Reporting

ISSN 2162-3082

2019, Vol. 9, No. 1

As an example of the growing issue regarding the size of intangibles on balance sheets, viewing one large firm in the table above which has been in the news of late, AT\&T, it can be seen AT\&T had total assets of approximately $\$ 403$ billion, and Goodwill of approximately $\$ 105$ billion (by far the largest Goodwill dollar amount amongst the firms examined) for the year 2015. It is noted that this Goodwill sum grew by approximately $\$ 31$ billion in just one year alone - principally because of AT\&T's DirecTV acquisition. Moreover, it had other intangibles of $\$ 121$ billion for a total intangibles amount of approximately $\$ 226$ billion, or $106 \%$ of its December 31, 2015 market capitalization, representing approximately $56 \%$ of total assets. If we subtract intangibles from total assets ( $\$ 403$ billion - $\$ 226$ Billion $=\$ 177$ billion) we see intangibles comprised approximately $126 \%$ of other assets. AT\&T's total intangibles alone exceeded its market capitalization by approximately $\$ 14$ billion. Compare that Goodwill amount ( $\$ 105$ Billion) above to the former AT\&T's approximately $\$ 2$ billion in Goodwill on approximately $\$ 60$ billion in assets in its December 1998 annual report to shareholders, and we see an explosive expansion in intangible values. One analyst estimates with the Time Warner acquisition, AT\&T's debt will increase from $\$ 119$ billion in 2016 to $\$ 170$ billion (Knutson, 2016). Something has dramatically changed, perhaps in part because of the change in business combination and impairment standards regarding intangibles today.

And recently in 2016, AT\&T announced its planned acquisition of Time Warner for approximately $\$ 108.7$ billion $-\$ 85.4$ billion in cash and stock with the remainder in debt assumption (Hagey, et al, 2016). One can only imagine how much intangible 'value' will be added to AT\&T's balance sheet after Time Warner's net assets are written up to fair market value.

However, this acquisition also raises another important matter regarding intangible values. Most of AT\&T's DirecTV's customer base pays at the high end of the pricing spectrum for television and cable like programming subscription services - an average of \$117 a month (Gryta, 2016). AT\&T has announced plans to offer DirecTV Now services based principally on Time Warner's programming content via streaming Internet services for $\$ 35$ a month, initially for 100 channels with a free Apple TV provided. Premium services are estimated to be priced at $\$ 50$ to $\$ 60$ per month when available (Gryta, 2016). This begs the question, how many customers will migrate away from AT\&T's higher priced DirecTV to its new lower priced DirecTV Now services? And what will such migration to AT\&T's DirecTV Now (or competitor services from the likes of Netflix, Hulu, Sling TV, et al) do to the supposed value gained in the DirecTV acquisition of just over one year ago? Will not this DirecTV Now offering along with like kind competitive offerings materially and negatively impact the value of AT\&T intangibles?

As an asset, Goodwill appears to help the acquirer in a business combination in sustaining the appearance of increasing enterprise value via increased assets, and in the firm's ability to show top and bottom line increases through additional revenues with no concomitant penalty in the form of additional expenses (Goodwill and other intangible asset impairment/expenses). What develops is a pattern of constraints wherein a primary, almost single focus on sustained growth and profit maximization ultimately leads to entity non-sustainability by placing gross overpayments for assets above net asset fair market values on the balance sheet. That is, long term sustainability may be negatively impacted in entities that pay large premiums over market values for net assets acquired above fair market value by showing such overpayments as assets versus period or transaction expenses. In concept, it could be said that managements and Boards of Directors are induced to grossly overpay for net assets acquired because there are material gains: enhanced enterprise valuations, positive stock price performance, an increased ability to borrow or raise other capital, and an ability to reward managers and employees with ever increasing 'in the money' options, etc. But the question remains, do such overpayments above market values enhance or limit sustainability?

Monga (2016) in The Wall Street Journal cites the work of economist Carol Corrado. Corrado shows that companies were investing approximately $14 \%$ of the private sector gross domestic product into non-physical assets (intangibles) in 2014. The investment in tangible assets (physical matter) in 2014 was approximately $10 \%$. Corrado posits this was a reverse of the situation of 40 years ago where investment in tangible assets was $13 \%$, and intangible was $9 \%$. Clearly technological advancements 


\section{$\triangle$ Macrothink}

International Journal of Accounting and Financial Reporting

ISSN 2162-3082

2019, Vol. 9, No. 1

have had an impact in the type of investments made; but 40 years ago, intangibles including Goodwill had to be systematically amortized (expensed) over not more than 40 years - a dramatic difference with the intangible's impairment (expense) standards of today.

\section{Possible Reasons for the Growth in Intangibles Including Goodwill}

Why might managements see the gross over payment above fair market value for net assets acquired as a tool of value - and top and bottom line enhancements? Simply, when in the second half of the life cycle in any industry, it becomes harder and harder to capture new un-captured customers. Hence growing a top and bottom line via organic growth becomes much more arduous than in the first half of the respective business life cycle. And, as Wall Street principally only rewards top and bottom line growth and market share gains period over period, firms in maturing markets need to show growth and increases in the top line and bottom lines above all else. And with intangibles not having to be systematically expensed, managements have a window of opportunity to drive for the brass ring - top line and bottom line growth, with no concurrent material acquisition overpayment expenses appearing on the income statement. This possible willingness to grossly overpay for net assets acquired above fair market value is even more likely so if CEO and CFO tenures are examined. Fortune Magazine reported that for the 500 largest companies in the U.S., the mean tenure for a CEO is 4.9 years (Sonnenfeld, 2015), and for CFOs, The Wall Street Journal reported the mean tenure was 5.6 years (Monga, 2015). Hardly a tenure long enough to worry about sustainability and the long term!

In the market as a function of time, if a primary focus on profit maximization is followed driven by an understanding of mean tenure times for senior officers, it almost universally will lead to corporate decline or demise - short term growth and profit maximization versus longer term sustainability strategies and actions.

And if we consider the short life cycles of a business enterprises averaging 12.5 years (Shore, 2013), here too we see relatively very short lives as in the mean tenure times of the CEO and CFO. Strong incentives for immediate gratification.

\section{Conclusions and Recommendations}

More assets on balance sheets today are of an intangible nature (including Goodwill) than at any previous time. With companies continuing to pay 30 to 50\% premiums for acquisitions and keeping such premiums on the books principally as Goodwill, unless and until the current standard regarding intangibles is changed, such inflated balance sheets will continue. Clearly, technological changes may be at the center of this shift in asset form, but it also appears that accounting standards have created a large inducement for companies to 'puff the value of their wares' by permitting for an overpaying (large premiums above market value) for net assets acquired in a business combination without such Goodwill and other intangible assets being systematically amortized (expensed). Moreover, such overpayments tend to not provide a needed market acceptable rate of return. Such behavior makes it most difficult to earn and sustain a market acceptable rate of return over the longer term because some large to very large intangible assets are providing little in the way of meaningful annual return contribution as seen in the AT\&T acquisition of DirecTV. At the same time, financial ratios are distorted as most often lofty intangible valuables, based on large premiums paid, distort (inflate) real total asset values as presented in the financial statements.

Additionally, with strict monitoring of horizontal acquisitions today as measured by the Herfindahl-Hirschman Index (HHI), used by the U.S. Government, entities will continue to have to move outside their core industry in making acquisitions in order to grow when in a period of market satiation. Here typically, core business expertise and knowledge will likely be of limited value. But the inducement to grow via acquisitions where large premiums are paid in the U.S. regulatory environment today, answers the question posited by Larry Greiner (1972) decades ago: what happens to entities when they pass from his fourth to fifth stage of life? The answer today is they limit their sustainability because of huge overpayments for intangible assets acquired. 


\section{Ml Macrothink}

International Journal of Accounting and Financial Reporting

ISSN 2162-3082

2019, Vol. 9, No. 1

Inasmuch as the impairment standards still provide wide discretion in their calculation even in the latest FASB draft regarding the impairment of intangibles, in order to return to the accounting underpinnings of making the prudent and conservative choice, the following is recommended:

1) Modify the FASB ASC 805 Business Combinations standard (and associated standards as needed) such that any premium paid by a successor entity for a business in a business combination above the market value as represented on a main stock exchange on the day before the proposed acquisition or merger is announced, be expensed upon deal closing. This would mitigate the large increases in intangibles created under current standards. And it would highlight how much management paid over the net fair market value of net assets acquired.

2) Reintroduce into the Statements of Financial Accounting Concepts (SFACs) the prudence and conservatism underpinnings in accounting previously found in FASB's CON 2.

3) Reintroduce the rational and systemic amortization of intangibles (excluding patents and copyrights, etc. if they have a statutory remaining life greater than 20 years) over a period not to exceed 20 years.

These recommended changes should help unmask gross overpayments above market values seen in business combinations of the past ten years and rationally and systematically expense intangibles over a reasonable period of time considering today's shorter life cycles.

\section{Acknowledgement}

Because this paper deals with material assets of claimed value, it is necessary to note nothing in this paper alleges wrong doing. Rather, the purpose of this paper is to highlight weaknesses in the accounting standards regarding intangibles, their values, their impairment, and the potential misdirection of the investing public by the permitted application of existing standards - the unintended consequences paradigm.

\section{References}

Argenti, J. (1976). Corporate Collapse - The Causes and Symptoms. John Wiley \& Sons, New York.

Cicero, M. (55 B.C.). A comparison with today appears to indicate situations repeat themselves. Retrieved from https://www.truthorfiction.com/cicero-plan/

Condon, B. (2016, July 1). As Desire to Acquire Mounts, So Does Risk of Losses. Associated Press. Retrieved from http://www.bigstory.ap.org/content/bernard-condon

De-Geus, A. (1999). The Living Company. Boston: Nicholas Brealey Publishing.

Financial Accounting Standards Board (FASB). (2016). FASB Accounting Standards Codification (ASC) and Concept Statements (SFACs). Retrieved from www.fasb.org

Financial Accounting Standards Board. (2016). The FASB in its Project Update, September 12, 2016, issued its Subsequent Accounting for Goodwill for Public Business Entities and Not-for Profit Entities. Retrieved

from

http://www.fasb.org/jsp/FASB/FASBContent_C/ProjectUpdatePage\&cid=1176163679475

Greiner, L. (1972). Evolution and Revolution as Organizations Grow (pp. 37-46). Harvard Business Review, Cambridge, MA.

Gryta, T. (2016, October 20). AT\&T Tries to Shake Up Pay TV. The Wall Street Journal, B2.

Hagey, K, Cimilluca, D., \& Ramachandran, S. (2016, October 24). AT\&T Deal Came Together Swiftly. The Wall Street Journal, B1.

Herfindahl-Hirschman Index (HHI). (2010). See U.S. Department of Justice \& FTC. Horizontal Merger Guidelines, 5(3).

Khaldoun, I. (November, 1377). AL-MUQADDIMAH. Retrieved from http://www.muslimphilosophy.com/ik/klf.htm

Knutson, R. (2016, October 23). Buying Time Warner, Inc. will make AT\&T among the most heavily indebted companies on earth. The Wall Street Journal. 


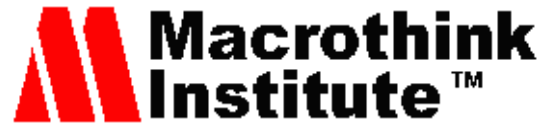

International Journal of Accounting and Financial Reporting

ISSN 2162-3082

2019, Vol. 9, No. 1

Monga, V. (2015, July 22). BOA CFO 4-Year Tenure: Shorter Than Average. The Wall Street Journal.

Monga, V. (2016, March 22). Accounting's New Problem. The Wall Street Journal, B5.

Nugent, J. (2013). Plan to Win. McGraw-Hill Publishers.

Nugent, J. (2016). Goodwill: The Illusion of Value?. Social Science Research Network (SSRN). Retrieved from http://ssrn.com/abstract $=2844775$

Senge, P. (2013). Leadership: A Master Class. From the MIT video collection on Sustainability and

Leadership. Retrieved from http://www.leadershipdigital.com/senge/?open-article-id=1802227\&article-title=leadership--a-masterclass\&blog-domain=wordpress.com\&blog-title=first-friday-book-synopsis

Shore, S. (2013). The Role of Culture in Implementing Sustainable Business Practices. An Unpublished Paper, Business School Lausanne.

The Free Dictionary. (n.d.). The Free Dictionary intangible definition. Retrieved from http://www.thefreedictionary.com/intangible

Thurm, S. (2012, August 14). Buyers Beware: The Goodwill Games. The Wall Street Journal.

Tytler, A. (1787). Life Cycle of a Democracy. Retrieved from https://en.wikipedia.org/wiki/Alexander_Fraser_Tytler,_Lord_Woodhouselee

Uniform Commercial Code. (n.d.). The U.S. Uniform Commercial Code. Retrieved from https://www.law.cornell.edu/ucc/9/9-102

Wagner, E. (2013). Five Reasons 8 Out Of 10 Businesses Fail. Forbes Magazine. Retrieved from http://www.forbes.com/sites/ericwagner/2013/09/12/five-reasons-8-out-of-10-businesses-fail

\section{Appendix: Terms and Acronyms}

$10 \mathrm{~K}$ - SEC required annual financial reporting form

$10 \mathrm{Q}$ - SEC required quarterly financial reporting form

AICPA - American Institute of Certified Public Accountants

APB - Accounting Principles Board (the precursor to the FASB)

ASC - Accounting Standards Codification

ASU - Accounting Standards Update

CONs - FASB Concept Statements now termed SFACs

FASB - Financial Accounting Standards Board (successor to the APB)

FMV - Fair Market Value

GAAP - Generally Accepted Accounting Principles

SEC - U.S. Securities and Exchange Commission

SFAC - Statement of Financial Accounting Concepts

\section{Copyright Disclaimer}

Copyright for this article is retained by the author(s), with first publication rights granted to the journal.

This is an open-access article distributed under the terms and conditions of the Creative Commons Attribution license (http://creativecommons.org/licenses/by/4.0/) 